\title{
A new trematode species Neoplagioporus kajika sp. n. (Digenea: Opecoelidae), parasitic in the Japanese fluvial sculpin, Cottus pollux (Osteichthyes: Scorpaeniformes: Cottidae), from Japan
}

\author{
Misako Urabe ${ }^{1,2}$ and Eriko Higa ${ }^{1,3}$ \\ ${ }^{1}$ Department of Natural Sciences, Fukuoka University of Education, Akamabunkyo-machi 1-1, Munakata, Fukuoka 811-4192, \\ Japan; \\ ${ }^{2}$ Present address: Department of Ecosystem Studies, School of Environmental Science, The University of Shiga Prefecture, \\ Hassaka-cho 2500, Hikone, Shiga 522-8533, Japan; \\ ${ }^{3}$ Present address: Fishery Research Laboratory, Graduate School of Bioresource and Bioenvironmental Sciences, Kyushu \\ University, Tsuyazaki 2506, Fukutsu, Fukuoka 811-3304, Japan
}

Key words: Digenea, Neoplagioporus kajika, adult, freshwater sculpin, Cottus pollux, Japan

\begin{abstract}
The adult morphology is described and illustrated of Neoplagioporus kajika sp. n. (Digenea: Opecoelidae) found in the Japanese fluvial sculpin Cottus pollux Günther (Osteichthyes: Scorpaeniformes: Cottidae) collected in the Naka River at Terase Bridge, Narutake, Nakagawa Town, Fukuoka Prefecture, Kyushu, Japan. This new species is characterized by that the body shape is oval, that the intestinal caeca end posteriorly at the middle level of the testicular region, that the ovary is trilobed, and that the vitelline follicles are distributed between the pharyngeal level and usually the posterior end of body and fill up the lateral fields of body. The new species is different from three hitherto known Neoplagioporus species, N. zacconis (Yamaguti, 1934) Shimazu, 1990 (type species), N. ayu (Takahashi, 1928) Shimazu, 1990, and N. elongatus (Goto et Ozaki, 1930) Shimazu, 1990, in a combination of these characteristics. The new species is considered mainly infective to C. pollux in the river.
\end{abstract}

The genus Neoplagioporus Shimazu, 1990 (Digenea: Opecoelidae: Plagioporinae) consists of three species, $N$. zacconis (Yamaguti, 1934) Shimazu, 1990 (type species), N. ayu (Takahashi, 1928) Shimazu, 1990, and N. elongatus (Goto et Ozaki, 1930) Shimazu, 1990, which have been known to be parasitic in the intestine of freshwater fishes in Japan and Korea (Takahashi 1928, Goto and Ozaki 1930, Yamaguti 1934, 1938, Shimazu 1990, Kim et al. 1998, Public Works Research Institute 2002, Shimazu and Urabe 2005). Cribb (2005) gives a taxonomic discussion on the genus.

We examined freshwater fishes of several species collected in a river in Kyushu, Japan for helminth parasites in 2003 to 2005. Digenean specimens of Neoplagioporus found in the sculpin, Cottus pollux Günther, were morphologically different from those of the three known species mentioned above. We aim at describing the specimens found in the sculpin as a new species of the genus in this paper.

\section{MATERIALS AND METHODS}

A total of 17 individuals of the sculpin Cottus pollux Günther (Osteichthyes: Scorpaeniformes: Cottidae) were collected in the Naka River at Terase Bridge, Narutake, Nakagawa Town, Fukuoka Prefecture, Kyushu, Japan, in 2003 to 2005. Seven of them harboured specimens of the new species in the intestine (prevalence 0.4 ; mean intensity 15.6 ).
The specimens taken into account in the species description were obtained from a single female fish $60.3 \mathrm{~mm}$ in standard length, collected at Terase Bridge on March 5, 2005. The type series consists of 12 mature specimens of a total of 20 from the fish.

In addition, two specimens were obtained from fishes besides sculpins collected in Sakuta channel at Yamada, which is about $2 \mathrm{~km}$ away from Narutake. One mature specimen was found in the intestine of 1 of 58 individuals examined of Zacco temmincki (Temminck et Schlegel) (Osteichthyes: Cypriniformes: Cyprinidae). The infected fish was collected on April 23,2004 . One immature specimen was found in 1 of 15 individuals examined of Pseudogobio esocinus (Temminck et Schlegel) (Osteichthyes: Cypriniformes: Cyprinidae). The infected fish was collected on March 28, 2004.

Worms were slightly pressed under coverslips and fixed in AFA for one day. They were stained with Heidenhain's iron haematoxylin, and mounted in Canada balsam. Drawings were made with the aid of a drawing tube. Measurements (length by width) are given in millimetres unless otherwise stated. The type and voucher specimens studied have been deposited in the National Science Museum, Tokyo (NSMT) and the Institute of Parasitology, Academy of Sciences of the Czech Republic, České Budějovice.

\section{DESCRIPTION}

Neoplagioporus kajika sp. n. Fig. 1A-E

Description. Based on 12 gravid type specimens. Body oval, not oculate, $1.42-2.08$ by $0.59-0.86$. Tegu-

Address for correspondence: M. Urabe, Department of Ecosystem Studies, School of Environmental Science, The University of Shiga Prefecture, Hassaka-cho 2500, Hikone, Shiga 522-8533, Japan. Phone: ++81 749288 308; Fax: ++81 749288 463; E-mail: urabe@ses.usp.ac.jp 

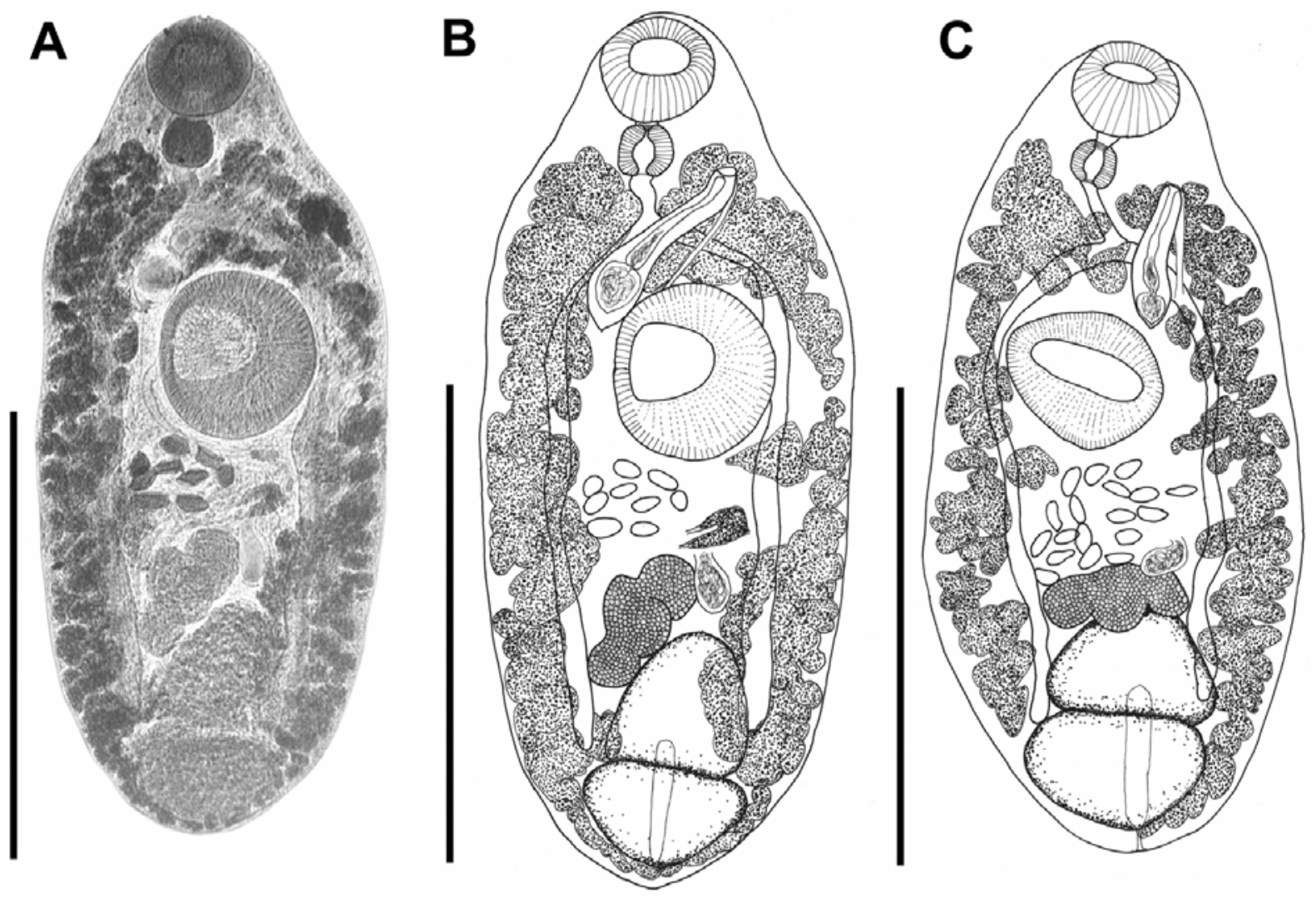
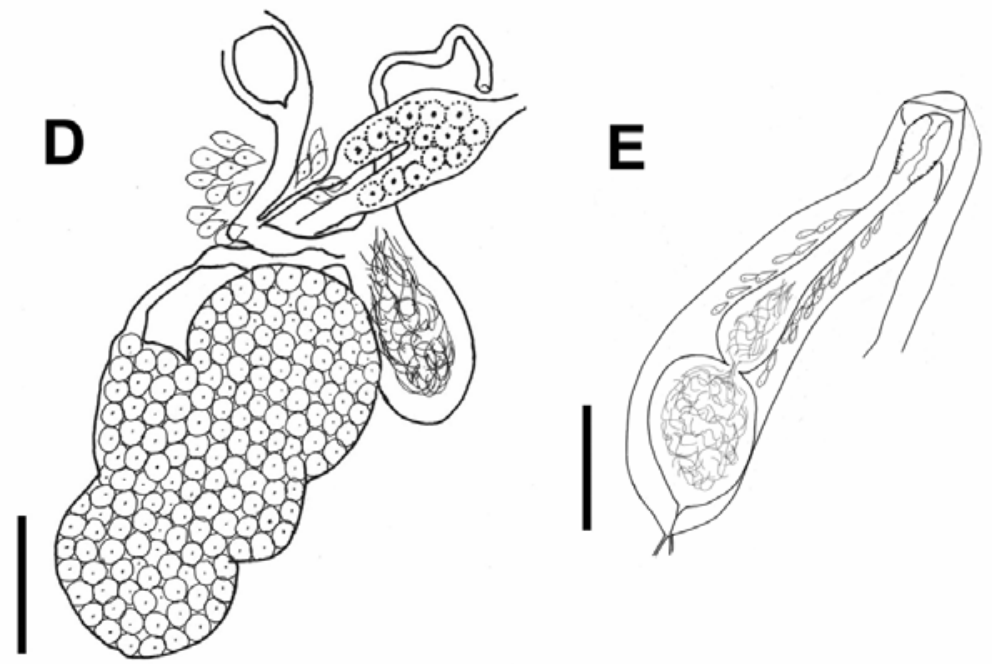

Fig. 1. Neoplagioporus kajika sp. n. from Cottus pollux, photograph (A) and line drawings. A, B - entire worm, ventral view (holotype); C - entire worm, ventral view (paratype); D - ovarian complex, ventral view (holotype); $\mathbf{E}$ - male terminal genitalia, ventral view (holotype). Scale bars: $\mathrm{A}-\mathrm{C}=1 \mathrm{~mm} ; \mathrm{D}, \mathrm{E}=0.1 \mathrm{~mm}$. ment smooth. Oral sucker ventroterminal, $0.19-0.23$ by 0.19-0.27. Prepharynx short. Pharynx spherical, $0.08-0.11$ by $0.09-0.13$. Oesophagus $0.09-0.21$, bifurcating at about middle level between pharynx and ventral sucker. Intestinal caeca extending to middle level of testicular region. Ventral sucker just anterior of mid level of body, $0.28-0.38$ by $0.27-0.36$; sucker width ratio 1:1.17-1.68. Testes entire, oval or elliptical, almost tandem, contiguous, in posterior half of hindbody; anterior testis $0.17-0.39$ by $0.20-0.42$, posterior $0.17-0.39$ by $0.25-0.42$. Cirrus pouch claviform, anterior to or slightly overlapping ventral sucker. Seminal vesicle internal, distinctly divided into two portions; posterior portion elliptical or round, anterior elongated. Pars prostatica short, surrounded by prostatic cells. Cirrus short. Genital atrium small. Genital pore sinistral, extracaecal, slightly posterior to pharyngeal level. Ovary trilobed, median or dexstrosubmedian, usually intercaecal, pretesticular. Seminal receptacle club-shaped, submedian, preovarian or partially overlapping ovary. Laurer's canal opening dorsally, near left intestinal caecum. Ootype-complex just anterior to ovary, and 
often overlapping seminal receptacle. Mehlis' gland well developed. Uterus coiled a few times between anterior testis and ventral sucker, intercaecal. Eggs oval, numbering 7-33 per worm, $61-83$ by $34-49 \mu \mathrm{m}$, one side hollow, the other side sometimes protruding, not fully embryonated when laid. Vitelline follicles distributed along intestinal caeca, anteriorly to pharyngeal level and confluent there, posteriorly to posterior end on both sides of body and confluent there, or to posterior end on left side of body but only to testicular region on right side, or rarely to posterior border of posterior testis on both sides, filling up both lateral fields of body. Excretory vesicle I-shaped, reaching anteriorly to about posterior level of anterior testis. Excretory pore posteroterminal.

H o s t s : Cottus pollux Günther (Osteichthyes: Scorpaeniformes: Cottidae) (type host), Zacco temmincki (Temminck et Schlegel) (Osteichthyes: Cypriniformes: Cyprinidae), and Pseudogobio esocinus (Temminck et Schlegel) (Osteichthyes: Cypriniformes: Cyprinidae).

Site of infection: Intestine.

T y p e 1 o c a 1 i t y: Naka River, Terase Bridge, Narutake, Nakagawa town, Fukuoka Prefecture, Kyushu, Japan

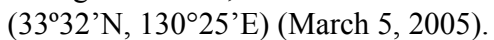

$\mathrm{S} p$ e c i m e n s d e p o s i t e d : Holotype NSMT-Pl 5445 from C. pollux; 11 paratypes NSMT-Pl 5446-5455 and Institute of Parasitology, Academy of Sciences of the Czech Republic, České Budějovice D-591 from C. pollux. Voucher specimens NSMT-Pl 5456 from Z. temmincki and NSMT-Pl 5457 from $P$. esocinus.

E t y m o lo g y: The specific name "kajika" is the Japanese common name of the type host.

Remarks. Following the key given by Cribb (2005), the species here described fits well in the genus Neoplagioporus Shimazu, 1990. Neoplagioporus kajika resembles $N$. zacconis. However, the new species is different from it in having the peripheral lateral fields of body being filled up with the vitelline follicles, while $N$. zacconis has the peripheral fields free from vitelline follicles. Specimens of $N$. zacconis collected from $Z$. platy- pus (Temminck et Schlegel) captured by us in the Naka River (NSMT 5458-5459) were smaller in body size (based on 15 specimens; $0.44-0.66$ in body width) than N. kajika. However, Yamaguti's specimens $(1934,1938)$ measured by Shimazu (1990) are larger (0.67-1.50 in body width) and almost same size as the new species. Thus, body size is not useful to characterize these two species. The new species is different from $N$. elongatus in having an oval body shape, smaller eggs measuring $61-83$ by $34-49 \mu \mathrm{m}$ instead of $76-96$ by $44-60 \mu \mathrm{m}$ (Shimazu 1990) and $94-110$ by $54-68 \mu \mathrm{m}$ (Shimazu and Urabe 2005), and the vitelline follicles extending anteriorly to the pharyngeal level. The new species is distinguishable from N. ayu as described by Shimazu (1990) by that the intestinal caeca extend posteriorly only to the testicular region of the body instead of to near posterior end of the body, that the testes are located in the posterior half instead of the middle third of the hindbody, that the vitelline follicles are distributed anteriorly to the pharyngeal level instead of the bifurcal, that the Laurer's canal opens near the left caecum instead of median, and that the excretory vesicle extends to the anterior testis instead of the posterior.

In the present study, specimens of the new species were obtained mainly from $C$. pollux, and rarely from $Z$. temmincki and $P$. esocinus. Specimens of $N$. zacconis (NSMT 5468-5469) were obtained mainly from $Z$. platypus and rarely $Z$. temmincki in the same river. Those of $N$. elongatus (NSMT 5460-5467) were obtained from P. esocinus, Pungtungia herzi Herzenstein (Cyprinidae) and Coreoperca kawamebari (Temminck et Schlegel) (Perciformes: Sinipercidae) in the same river. No specimens of $N$. zacconis or $N$. elongatus were found in C. pollux. This indicates that the three Neoplagioporus species in the Naka River have different host range and the new species is principally infective to C. pollux.

Acknowledgements. We are grateful to Professor T. Shimazu, Nagano Prefectural College, for his kind comments on the draft.

\section{REFERENCES}

CRIBB T.H. 2005: Family Opecoelidae Ozaki, 1925. In: A. Jones, R.A. Bray and D.I. Gibson (Eds.), Keys to the Trematoda. Volume 2. CABI Publishing and the Natural History Museum, UK, pp. 443-531.

GOTO S., OZAKI Y. 1930: Brief notes on new trematodes III. Jpn. J. Zool. 3: 73-82.

KIM K.H., CHO J.B. RIM H.J. 1998: Neoplagioporus zacconis (Trematoda: Opecoelidae) from intestine of the pale chub, Zacco platypus, in Korea. Korean J. Parasitol. 36: 199-202.

PUBLIC WORKS RESEARCH INSTITUTE 2002: [Annual report of Aqua Restoration Research Center 2001]. (In Japanese.)

SHIMAZU T. 1990: Trematodes of a new genus, Neoplagioporus gen. n. (Digenea: Opecoelidae: Plagioporinae), and an unidentified opecoelid from freshwater fishes of Japan. Jpn. J. Parasitol. 39: 384-396.

SHIMAZU T., URABE M. 2005: Digeneans found in freshwater fishes of the Uji River at Uji, Kyoto Prefecture, and the Takami River at Higashiyoshino, Nara Prefecture, Japan. J. Nagano Pref. Coll. 60: 1-14.

TAKAHASHI S. 1928: On a new trematode Podocotyle ayu $\mathrm{n}$. sp. from the intestine of Plecoglossus altivelis (T. and S.). Arb. Med. Univ. Okayama 1: 51-56.

YAMAGUTI S. 1934: Studies on the helminth fauna of Japan. Part 2. Trematodes of Fishes, I. Jpn. J. Zool. 5: 249-541.

YAMAGUTI S. 1938: Studies on the helminth fauna of Japan. Part 21. Trematodes of Fishes, IV. Author's publication, Kyoto, pp. 1-139, 1 pl. 